\title{
Ana Crespo: a 70th birthday tribute
}

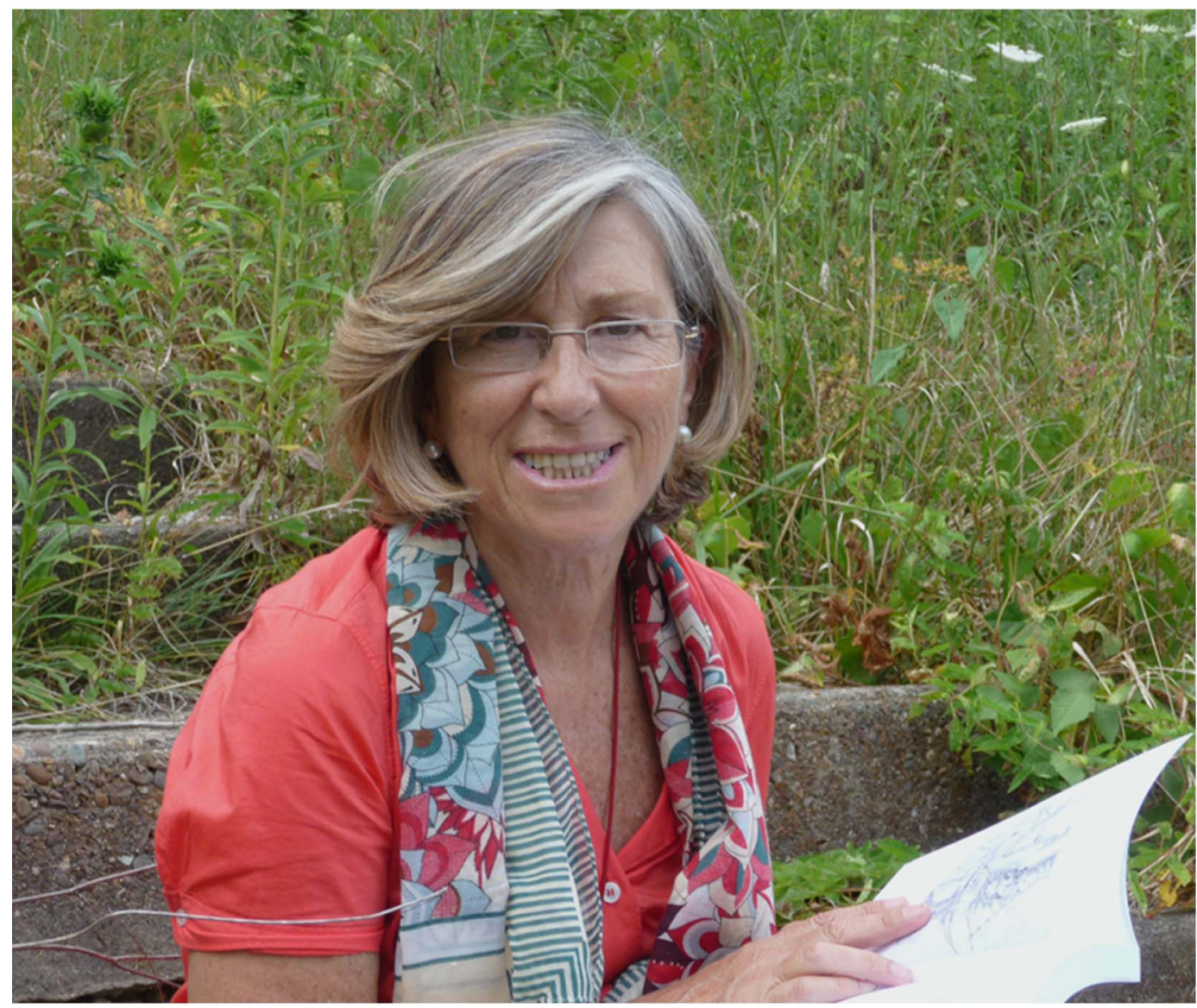

Ana Maria Crespo de las Casas was born in 1948 and grew up on Tenerife in the Canary Islands. She has always kept this archipelago close to her heart, not only because of her family there, but also because of her fascination with its flora and vegetation. Ana moved to Madrid to study biology at the Universidad Complutense de Madrid in 1970 and she defended her thesis in 1973 with summa cum laude; it was on the flora and vegetation of epiphytic lichens of the Sierra de Guadarrama. Her thesis was co-supervised by Gerhard Follmann who was at the Naturkundemuseum im Ottoneum in Kassel (Germany) in the 1970s. Her early career was influenced by the phytosociological school of Salvador Rivas-Martínez in Madrid, who was also her Ph.D. advisor, and focused on the application of phytosociology to lichens. Other lichenological teachers in her early years included Josef Poelt and George Clauzade. Since there was no lichenological tradition in Spain, something difficult to imagine nowadays with the large number of highly active 
lichenologists in the country, Ana quickly developed international relationships and was successful in networking with colleagues all over Europe. In her postdoctoral research Ana focused on phytosociology, floristics and taxonomy of Mediterranean lichens. At the same time, she was teaching at the Universidad Complutense and trained graduate students in lichenology; two of us were among her first graduate students. During her career at the university, she was promoted to Full Professor (Catedrática) in 1983 in the Pharmacy Faculty, and continued her work on taxonomy and systematics of lichens with the main focus on the western Mediterranean and Macaronesia.

After the first re-election of the Socialist government of Felipe González, Ana accepted the offer to join the government to develop a modern science concept for Spain. She served as Director General for the State Secretary of the Ministry for Universities and Research from 1987 to 1991, and then as Director General for Universities until 1993. During her time in politics she oversaw important initiatives to reform science and universities in Spain, and to integrate them into the European scientific landscape, paving the way for its excellent current state. After leaving active politics Ana reinvented her scientific career and returned to being an apprentice by spending a year at the IMI in Egham (UK) to learn molecular techniques. Once back in Madrid she jump-started what would become a most prolific endeavour understanding the evolutionary history of the Parmeliaceae. At the time, the generic classification of this family was in a state of chaos, with lichenologists from different continents employing widely differing approaches and engaging in heated debates. Ana soon realized that genetic data could help to rationalize this discussion and arrive at a consensus classification, an approach that culminated in 2010 with a paper summarizing the classification, including as coauthors most of the proponents of incompatible classifications (Crespo et al. 2010).

Ana was in the vanguard of adopting new technological developments (molecular analysis and genetic databases) which led to a revival of biological systematics based on phylogeny (Integrative Taxonomy). She was among the first to detect cryptic lineages in lichenized fungi and recognize their importance for estimates of species diversity. Her work demonstrated that the phenotypic features of a species do not always reflect the true genetic diversity present and highlighted the high phenotypic plasticity in lichenforming fungi. Her investigations have changed our view of species delimitation in lichen fungi. In addition to her work in systematics and taxonomy, Ana also has strong interests in using lichens in monitoring air pollution and testing potential pharmacological applications. In the 1970 s she was a pioneer in introducing to Spain techniques for monitoring atmospheric pollution and environmental quality. She has been the principal supervisor for twelve graduate students, advised numerous postdoctoral researchers and hosts a never-ending stream of scientific visitors to her laboratory. Ana has published more than 170 scientific papers and has served on numerous committees to evaluate scientific proposals. In addition to her scientific research and teaching duties, she has also served for several years as director of the botanical department of the university. Ana is President of the Natural Sciences section of the Royal Spanish Academy of Sciences, Vice President of the International Association for Lichenology (IAL), member of the council of the International Association of Plant Taxonomy, and serves on the editorial board of the Lichenologist.

Ana's scientific contributions have been widely recognized. She received the Medal of the Menéndez y Pelayo International University in 1993, and has been a research associate of The Field Museum since 2005. In 2012 she was elected into the Royal Spanish Academy of Sciences and received the Acharius Medal of the IAL in the same year. She was ranked among the top $1 \%$ of highly cited researchers in the 2013 list from Thomson Reuters (Docampo \& Torres-Salinas 2013). Her peers dedicated several species and genera of lichens, and one grass species to her, including the generic 
names Crespoa, Cresponea and Cresporhaphis (Aguirre-Hudson 1991; Egea \& Torrente 1993; Hawksworth 2011; Lendemer \& Hodkinson 2012).

Given the limited space available, we were only able to ask a small number of Ana's friends and close colleagues to contribute a manuscript to this Festschrift. Nonetheless we hope that it mirrors the principal lichenological topics in which she has been engaged throughout her career. Ana's scientific contributions to lichenology are recognized worldwide. Spanish lichenologists are deeply indebted to Ana's ground-breaking research, collegiality and mentorship, and we happily consider ourselves to be standing on her shoulders.

REFERENCES

Aguirre-Hudson, B. (1991) A taxonomic study of the species referred to the ascomycete genus Leptorhaphis. Bulletin of the British Museum (Natural History), Botany 21: 85-192.
Crespo, A., Kauff, F., Divakar, P. K., del Prado, R., Pérez-Ortega, S., Amo de Paz, G., Ferencova, Z., Blanco, O., Roca-Valiente, B., Núñez-Zapata, J., et al. (2010) Phylogenetic generic classification of parmelioid lichens (Parmeliaceae, Ascomycota) based on molecular, morphological and chemical evidence. Taxon 59: 1735-1753.

Docampo, D. \& Torres-Salinas, D. (2013) La nueva lista de investigadores altamente citados de Thomson Reuters y el Ranking de Shanghai: situación de España y mapa universitario. El Profesional de la Información, mayo-junio 22 (3): 264-272.

Egea, J. M. \& Torrente, P. (1993) Cresponea, a new genus of lichenized fungi in the order Arthoniales (Ascomycotina). Mycotaxon 48: 301-331.

Hawksworth, D. L. (2011) Parmotrema subgen. Crespoa subgen. nov. for the Canoparmelia crozalsiana clade. Lichenologist 43: 647-648.

Lendemer, J. C. \& Hodkinson, B. P. (2012) Recognition of the Parmelia crozalsiana group as the genus Crespoa. North American Fungi 7: 1-5.

\section{Pradeep K. Divakar, Eva Barreno, Leopoldo Sancho and H. Thorsten Lumbsch}

